University of Rhode Island

DigitalCommons@URI

Open Access Master's Theses

1970

\title{
A Study of the Effect of Ion-Exchange Resin Particle Size on Flourescent X-Ray Intensity
}

Alfred Lapham Allen

University of Rhode Island

Follow this and additional works at: https://digitalcommons.uri.edu/theses

\section{Recommended Citation}

Allen, Alfred Lapham, "A Study of the Effect of Ion-Exchange Resin Particle Size on Flourescent X-Ray Intensity" (1970). Open Access Master's Theses. Paper 1099.

https://digitalcommons.uri.edu/theses/1099

This Thesis is brought to you for free and open access by DigitalCommons@URI. It has been accepted for inclusion in Open Access Master's Theses by an authorized administrator of DigitalCommons@URI. For more information, please contact digitalcommons-group@uri.edu. 
A STUDY OF THE EFFECT OF ION-EXCHANGE RESIN

PARTICLE SIZE ON FLUORESCENT X-RAY INTENSITY

BY

ALFRED LAPHAM ALLEN

A THESIS SUBMITTED IN PARTIAL FULFILLMENT OF THE REQUIREMENTS FOR THE DEGREE OF

MASTER OF SCIENCE

IN

NUCLEAR ENGINEERING

ONIVERSITY OF RHODE ISLAND

1970 
MASTER OF SCIENCE THESIS,

$\mathrm{OF}$

ALFRED LAPHAM ALLEN

Approved:

Thesis Committee: Cha1rman
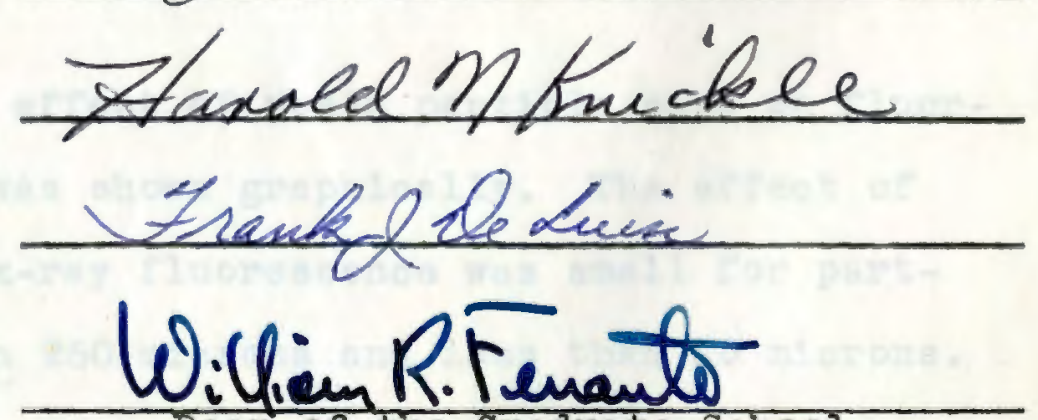

Dean of the Graduate School

UNIVERSITY OF RHODE ISLAND 


\section{ABSTRACT}

Each of five different size fractions of Chelex 100 ion-exchange resin was loaded with various amounts of copper. The weight mean diameters of the resin fractions were 478, 250, 112, 56, and 27 microns. The largest three fractions were commercially available as 50-100, 100-200 and 200-400 mesh size respectively, while the two smallest fractions were prepared by grinding and air elutriating the smallest commercially avallable fraction (112 microns).

The resin samples, loaded with the copper, were then analyzed with x-ray fluorescence. Five calibration curves were obtained for the five resin sizes showing the amount of copper versus the fluorescent $\mathrm{Cu} K \propto$ intensity. These calibration curves show that the relationship between the radiation intensity and the copper concentration is linear for each size.

The relative effect of resin particle size on fluorescent intensity was shown graphically. The effect of particle size on $x$-ray fluorescence was small for particles greater than 250 microns and less than 60 microns. A critical region existed, however, between these two sizes where particle size had a significant influence on the x-ray intensity. The small particle intensity was 
much greater than the large particle intensity. 


\section{ACKNOWLEDGMENT}

At this time, I should like to take the opportunity to extend gratitude to my major professor, Dr. Vincent Rose, for his advice and generous assistance. I am also grateful to the Agricultural Chemistry Department for the use of 1ts Atomic Absorption Spectrophotometer. Thanks are also expressed to Richard A. Romanelli for his valuable time and ald in figure preparations.

To my wife, for her devotion and patience in typing the manuscript, I would like to extend my sincerest appreciation. 


\section{TABLE OF CONTENTS}

I. INTRODUCTION....................... I

II. THEORY.......................... 4

III. EXPERIMENTAL WORK..................... 10

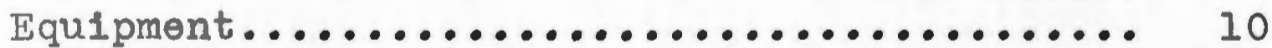

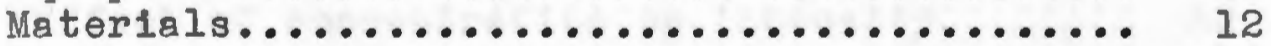

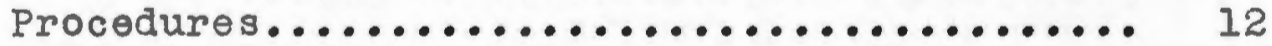

IV. RESULTS........................... 17

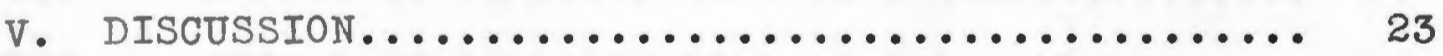

VI. CONCLUSIONS......................... 25

BIBLIOGRAPHY..................... 26

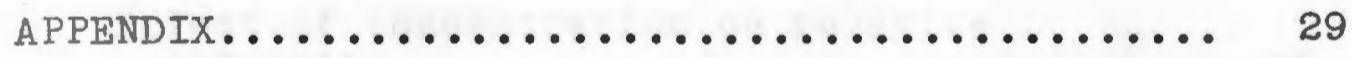

A. Original Data................... 29

B. Sample Calculations................ 48 


\section{LIST OF TABLES}

Table

I.

Properties of Chelex 100.

Page

II. Effect of particle size on relative intensity.

III. Effect of concentration on intensity....... 31

IV. Effect of concentration on intensity....... 32

v. Effect of concentration on intensity...... 33

VI. Effect of concentration on intensity...... 34

VII. Effect of concentration on intensity....... 35

VIII. Effect of particle size on relative intensity.

IX. Effect of concentration on relative

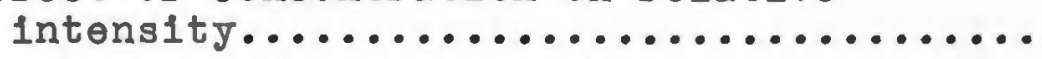

X. Effect of concentration on relative intensitj......................... 38

XI. Effect of concentration on relative

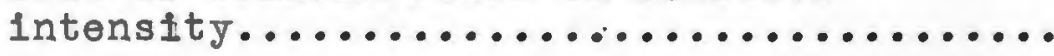

XII. Effect of concentration on relative

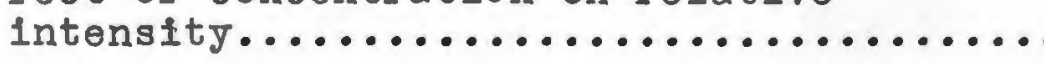

XIII. Effect of concentration on relative

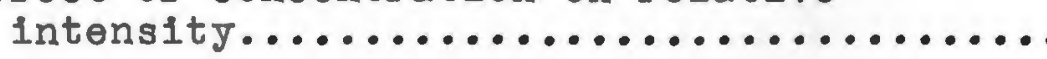

XIV. Absorbance readings from the atomic absorption spectrophotometer........... 42

XV. Settings for Perkin-Elmer spectrophotometer.

XVI. Settings for G.E. XRD-S5 x-ray diffraction

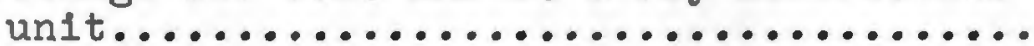

XVII. Settings for the Roller particle size

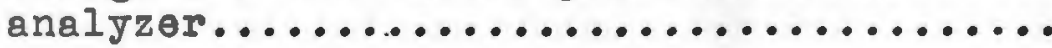


XVIII. Particle size distribution............. 46 


\section{IIST OF FIGURES}

Figure

1.

Shielding effect from large

Page

2. Theoretical relationship between relative intensity and particle size.............. 9

3. Ion-exchange equipment................ 11

4. Influence of three resin mesh sizes and amount of $\mathrm{Cu}$ absorbed on relative $\mathrm{x}$-ray fluorescence intensity.

5. Effect of particle size on relative intensity. 20

6. Effect of particle size on relative intensity. 21

7. Distribution curves for the five resin sizes.. 47 


\section{INTRODUCTION}

Accurate determination of copper in water is important since copper is introduced into streams by corrosion of cooling equipment in the process and power industries, from dips and pickles used by the metal finishers, etc. Since small amounts of copper have an adverse effect upon living organisms, including fish and shellfish, a quick and accurate method for determining the amount of copper in water is necessary (15).

The usual technique for trace analysis of copper in water consists of removing the copper from the water with ion-exchange materials, then eluting from the resin to give a concentrated solution and analyzing by routine chemical methods. In recent work, filter paper loaded with 1on-exchange material has been used to collect metal 1ons $(2,5,12)$. The lons are analyzed on the paper by $x$-ray fluorescence. These papers require recycling of the solution several times and have a limited capacity. In order to eliminate the problems in the paper method, it is proposed that the lons be collected directly on standard columns and a representative sample of the resin be analyzed using $x$-ray fluorescence analysis. Previous $x$-ray fluorescence work with chemical powders indicates that particle 
size affects the analytical results $(3,4,8)$. This investigation shows the effect of resin particle size on the uptake and analysis of copper from water using $x$-ray fluorescence.

The effect of particle size on $x$-ray fluorescence intensity for various minerals hes long been recognized. Fonda (7) exposed particulate target material of various sizes to high energy electrons and observed the particle size effect on the resulting fluorescent emission intensity. Bernstein (4) has noted that the particle size of a material may effect not only its own intensity but also the intensity of another component in the mixture. He observed that if the particle size of two components were reduced uniformly, the intensity of one would decrease while the intensity of the other would increase.

Other investigators have observed the effect of particle size on $x$-ray fluorescent intensity for various elements and minerals. Gunn (8) noted that both particle size and surface irregularities affect $x$-ray fluorescence. He indicated that a smooth surface and a small particle size had a tendency to increase the $x$-ray intensity. Bernstein (3), in an earlier publication, observed that particle size effects could seriously reduce both precision and accuracy of analytical results. Thus there is a need to investigate the effect of ion-exchange resin on $x$-ray fluorescence so that a proper sized resin can be 
selected.

Five ranges of particle size were investigated. Three sizes were commercially available, 50-100, 100-200, and 200-400 mesh resin, while two smaller size ranges were obtained by grinding and then air elutriating the 200-400 mesh resin. This study is concerned with one particular resin, Dowex A-1. Since the sodium form of Dowex A-1 has a large affinity for $\mathrm{Cu}^{+}+$ion $\left.(\mathrm{Cu} / \mathrm{Na})>100\right)$, it is commonly used to preferentially remove copper from solutions. 


\section{THEORY}

The pertinent principles and theory of x-ray fluorescence and the effect of particle size on the fluorescence can be briefly described as follows. A fast moving electron, upon impact with matter, will lose its energy and produce electromagnetic radiation which can be continuous (bremstrahlung) and/or characteristic radiation (definite wavelength). Bremsstrahlung is caused by the deceleration of the electron which loses anywhere from zero to all of its kinetic energy in the form of continuous (white) radiation. Characteristic radiation is caused by the vacancies in the excited atoms which are filled by electrons from the outer shells. Upon "falling back" to the ground state, the atoms emit discrete amounts of energy in the form of electromagnetic radiation of a definite wavelength.

In copper fluorescence analysis, $K$ electrons are expelled by high energy tungsten x-rays. Copper emits characteristic $\mathrm{K}$ radiation of which $\mathrm{Cu} \mathrm{K} \propto\left(1.54 \mathrm{~A}^{\circ}\right)$ is the. strongest and, therefore, most usefully applied component.

In order to distinguish the $\mathrm{Cu} \mathrm{K} \propto$ radiation from radiation from the $x$-ray tube and the continuous radiation from the sample, an x-ray diffractometer is used. Elec- 
tromagnetic radiation will be diffracted at crystallographic planes of an analyzing crystal at a perticular angle if the wavelength of the radiation is in the same order of magnitude as the interplanar spacing of the crystal. Diffraction follows Bragg's law:

$$
\mathrm{n} \lambda=2 \mathrm{~d} \sin \theta \theta
$$

where $n$ is the order of reflection, $\lambda$ is the wavelength of the radiation in Angstroms $\left(10^{-8} \mathrm{~cm}\right)$, d is the interplanar spacing of the crystal in Angstroms, and $\theta$ is the angle of diffraction. In this particular case, LiF $\left(d=2.01 A^{\circ}\right)$ was used as the analyzing crystal.

In $x$-ray fluorescence analysis, 1t has been found that the intensity of a constituent in a sample, within limits, is directly proportional to its concentration in the sample. J.W. Mejer (II) expressed this dependency with the following relationship:

$$
I_{E=} \frac{K C_{E}}{\sum C_{1}(\mu / p)_{1}}
$$

where $I_{E}$ is the radiation intensity and $C_{E}$ is the concentration of the constituent in the sample, $\quad \sum c_{1}(\mu / p)_{1}$ is the mass absorption coefficient of the entire sample and $K$ is a proportionality constant which includes such factors as tube voltage, amperage, target element characteristics, and fluorescent jield of the element.

For the standard sample, the relationship is expressed as follows: 


$$
I_{s}=\frac{K c_{s}}{\sum c_{1}(\mu / \rho)_{s}}
$$

Since the concentration of copper in the standard samplo and the mass absorption coefficient are constant, the relationship can be written as $I_{s}=K \times K^{\prime}$ where $K^{\prime}={\frac{C_{s}}{\sum C_{1}(\mu / p)_{s}}}$.

For the resin sample, however, the mass absorption coefficient is not constant but is a weighted sum of the absorption coefficients of each component i.e.

$$
\sum c_{1}(\mu / \rho)_{1}=c_{1}(\mu / \rho)_{1}+c_{2}(\mu / \rho)_{2} \text { etc. }
$$

where $C_{1}$ is the concentration of each component in the sample. For a sample loaded with $10 \mathrm{mg} \mathrm{Cu}$, the concentration of the resin is approximately 400 times the concentration of the copper, while the absorption coefficient of the copper is approximately 10 times greater than the absorption coefficient of the resin. Thus it is safe to assume that the absorption coefficient for the sample is constant for small copper concentrations. Thie relationship between the intensity and the sample concentration now becomes $I_{E}=K \times C_{E} \times K^{\prime \prime}$. By combining these two relationships, one obtains $\frac{I_{E}}{I_{g}}=\frac{K C_{E} K^{\prime \prime}}{K}$ or $I_{E}=K^{\prime \prime} I_{s} C_{E}$. This expression shows that there is a linear relationship between the intensity and concentration of copper in the resin sample.

Previous investigators $(3,8)$ have observed particle size effects on $x$-ray intensity. They have all reached 
the same general conclusion that intensity of the fluorescence will increase with decreasing particle size.

Gunn (8) explained this dependence by observing the possible shielding effects that a large particle could possess. This concept is shown in Figure 1. If one considers the fluorescent radiation emitted only in the $Y$ direction, for a large particle, it can be seen that it 1s possible for the fluorescent radiation generated at P2 to be largely self-absorbed in the $Y$ direction before arriving at the surface of the particle. It can be seen that the intensity from P2 w1ll be somewhat less than that emerging from Pl. Because of the loss in intensity due to large particle shtelding, it is expected, therefore, that a sample of large particles will emit a lower fluorescent intensity than a sample of small particles.

Bernstein (4) thought that a higher intensity was due to a decrease in the percent volds as the particle size decreased. He found that, for particle thickness larger than the effective depth of $x$-ray penetration (infinite thickness, $T_{\infty}$ ), the intensity of the $x$-ray fluorescence decreased sharply as particle size increased. In addition, he found that the effect of particle size on intensity diminishes as the particle size becomes smaller than infinite thickness. Both of these effects are 1llustrated in Figure 2. 

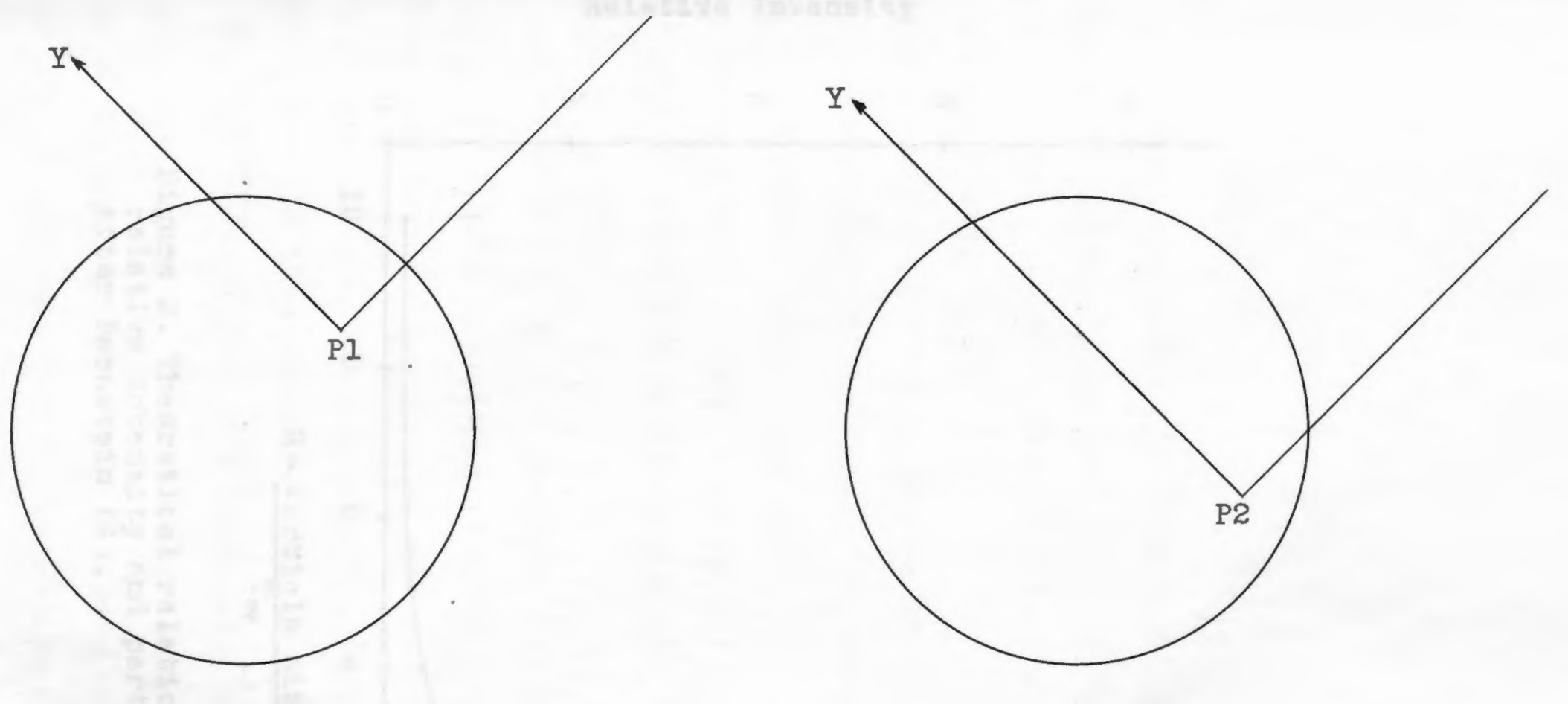

Figure 1. Shielding effect from large particles. 


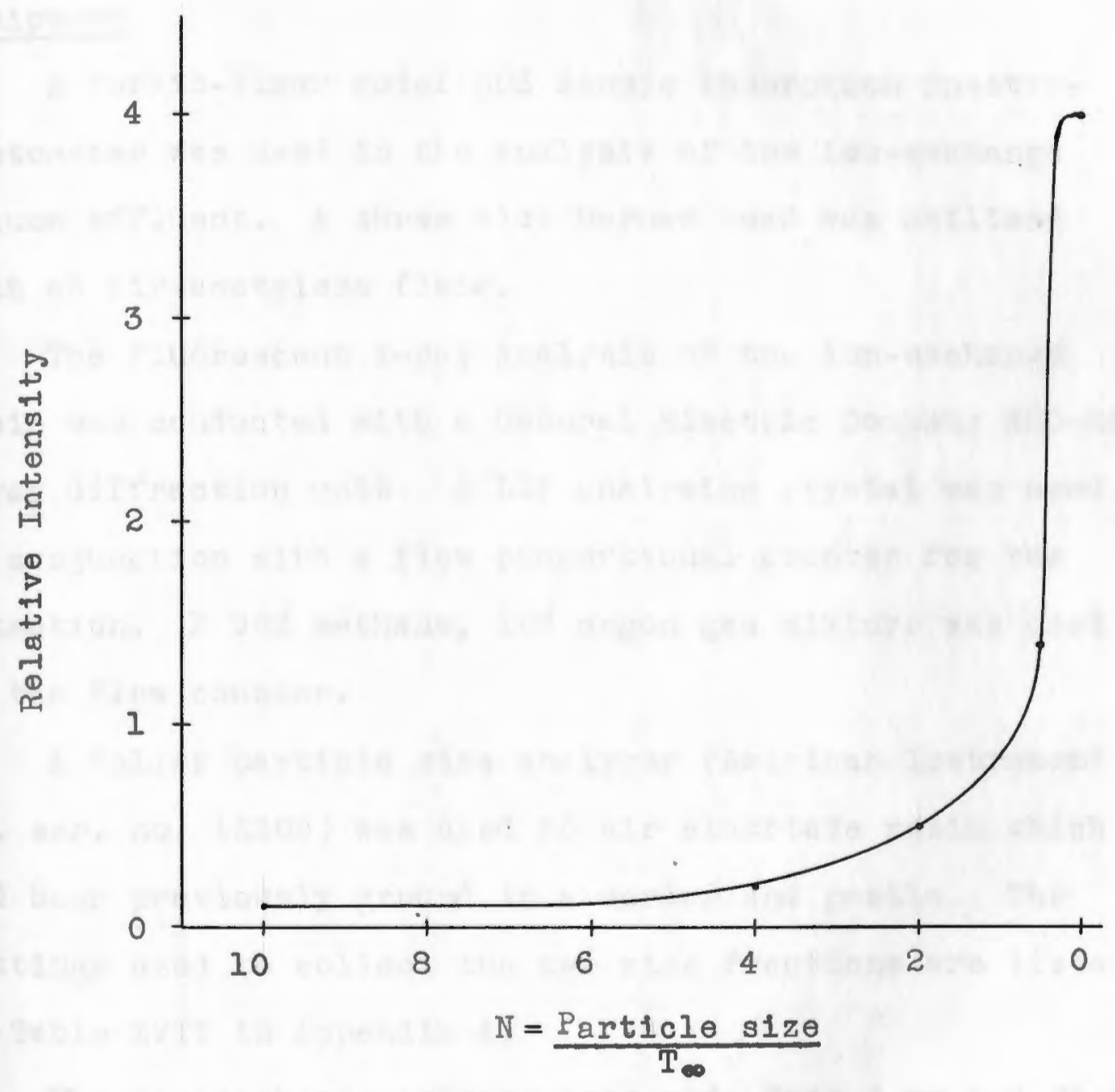

Figure 2. Theoretical relationship between relative intensity and particle size. After Bernstein (4). 


\section{EXPERIMENTAL WORK}

\section{Equipment}

A Perkin-Elmer Model 303 Atomic Absorption Spectrophotometer was used in the analysis of the ion-exchange column effluent. A three slot burner head was utilized with an air-acetylene flame.

The fluorescent $x$-ray analysis of the lon-exchange resin was conducted with a General Electric Company XRD-S5 x-ray diffraction unit. A LIF analyzing crystal was used in conjunction with a flow proportional counter for the detection. A $90 \%$ methane, $10 \%$ argon gas mixture was used in the flow counter.

A Roller particle slze analyzer (American Instrument Co. ser. no. 15309 ) was used to air elutrlate resin which had been previously ground in a mortar and pestle. The settings used to collect the two size fractions are listed in Table XVII in Appendix A.

The lon-exchange columns were made from $6 \mathrm{~mm}$ and $25 \mathrm{~mm}$ dlameter glass tubing. A glass wool plug was used to retain the resin in the column. The flow rate was maintained by use of a constant head tank. The columns are shown in F1gure 3. Four ml samples of the 50-100 mesh were placed Into $6 \mathrm{~mm}$ diameter columns. The other sizes were placed into $25 \mathrm{~mm}$ diameter columns. The capacity of the Dowex 


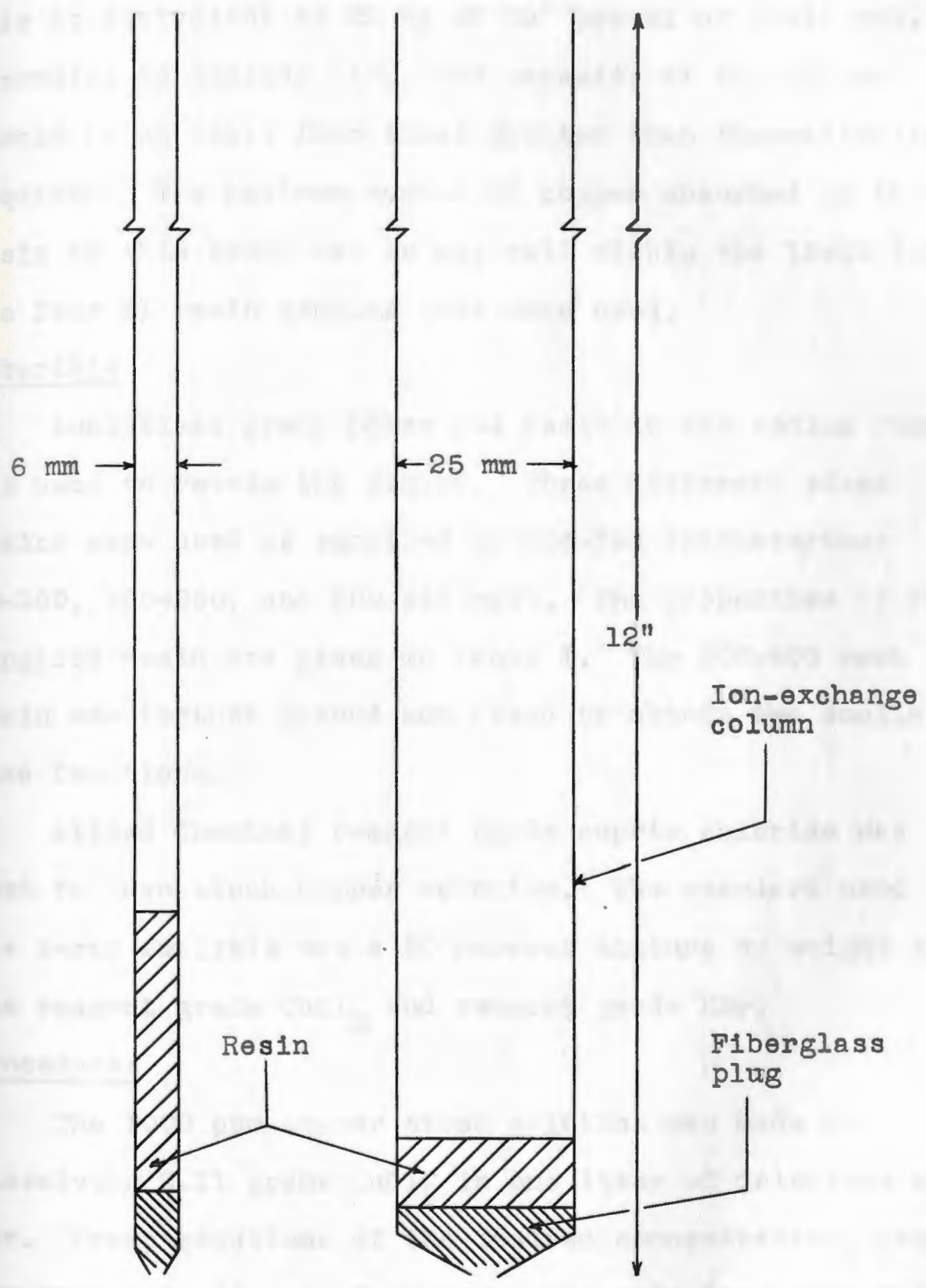

Figure 3. Ion-exchange equipment. 
A-l resin was 0.33 milifmoles of $\mathrm{Cu}^{++}$per ml of resin bed. Th1s is equivalent to $21 \mathrm{mg}$ of $\mathrm{Cu}^{++}$per ml of resin bed. According to Inczedy (10), the capacity of the column should be at least four times greater than theoretically required. The maximum amount of copper absorbed on the resin in this study was $10 \mathrm{mg}$, well within the limit for the four ml resin samples that were used. Materials

Analytical grade Dowex A-l resin in the sodium form was used to retain the copper. Three different sized resins were used as supplied by Blo-Rad Laboratories: $50-100,100-200$, and 200-400 mesh. The properties of the supplied resin are given in Table I. The 200-400 mesh resin was further ground and sized to obtain two smaller size fractions.

Allied Chemical reagent grade cupric chloride was used to make stock copper solution. The standard used in the $x$-ray analysis was a. 50 percent mixture by weight of the reagent grade $\mathrm{CuCl}_{2}$ and reagent grade $\mathrm{KBr}$. Procedures

The 1000 ppm copper stock solution was made by dissolving 2.11 grams $\mathrm{CuCl}_{2}$ in one liter of deionized water. Fresh solutions of the desired concentration, rangIng from 2 to $10 \mathrm{ppm}$ of copper, were made from the stock solution before each run.

The solution was eluted through resin at a flow rate 
TABLE I

PROPERTIES OF CHELEX 100

\begin{tabular}{|c|c|c|c|c|}
\hline Mesh S1zo & Shape & Active Group & Resin Type & Capacity \\
\hline $50-100$ & Spherical & & Weakly aold & 0.33 moles \\
\hline $100-200$ & Granular & $\mathrm{O}-\mathrm{CH}_{2}-\mathrm{N}_{2}-\mathrm{CH}_{2} \mathrm{COO}$ & cation chelat- & per $\mathrm{ml}$ of \\
\hline $200-400$ & Granular & & ing resin & $\mathrm{Cu}\left(\mathrm{NH}_{4}\right)$ \\
\hline
\end{tabular}

Order of Selectivity: Monovelent ions-- $H>L 1>N a>K$

Divalent ions -- $\mathrm{Cu}>\mathrm{Pb}>\mathrm{F}^{+3}>\mathrm{AI}>\mathrm{CH}^{+3}>\mathrm{N1}>\mathrm{Zn}>\mathrm{Ag}^{+1}>\mathrm{Co}>\mathrm{Cd}>\mathrm{F} \theta$

Maximum \% Impurities: Fe--0.0001\%

Cu- $-0.00008 \%$

N1- $-0.000005 \%$ 
of $35 \mathrm{ml} / \mathrm{hr} \mathrm{cm}^{2}$ for the $6 \mathrm{~mm}$ columns and at $2 \mathrm{ml} / \mathrm{hr} \mathrm{cm}^{2}$ for the $25 \mathrm{~mm}$ columns. After the copper solutions were passed through the resin, the effluents were analyzed with the atomic absorption spectrophotometer to determine whether all the copper was removed by the ion-exchange resin.

The smallest size fraction (welght mean diameter $=27 \mu$ ) could not be run in column operation because of the large pressure drop across the bed. A batch procedure, described by Inczedy (10), was used instead. The resin was placed In a beaker with the copper solution and stirred intermittantly for about one hour. The solution was then filtered to collect the resin. The water was tested for presence of copper, and the resin was analyzed on the x-ray unit.

In order to come to any conclusions about the particle size effect on $x$-ray intensity, the actual size distribution for each mesh range had to be known. From this distribution, a mean value for the particle could be calculated. For each mesh sịe, approximately 400 particles were counted and measured and a weight mean diameter was determined, using procedures described by Herdan (9). The distributions, plotted on $\log$ probability paper, are shown in Figure 7 in Appendix A.

To obtain resin particles smaller than 200-400 mesh size, the 200-400 mesh resin was dried and then ground in a mortar and pestle. After drying in an oven at $100^{\circ} \mathrm{C}$ for one hour, the resin was sleved through a 200 mesh 
screen prior to elutriation. A portion of the ground sample was placed in the sample holder of the air elutriator. By knowing the density and the particle size of the resin desired, appropriate air flow rates and cylinder selection can be made by consulting the operator's manual (1). The welght mean diameters of the two size fractions were 56 and 27 microns.

Appropriate settings for the spectrophotometer were obtained from the Perkin-Elmer Model 303 instruction manual (13). A wavelength setting of $3247.5 \mathrm{~A}^{\circ}$ was used for copper. The values for the varlous settings are given in Table XV of the appendix. The spectrophotometer was calibrated by obtaining absorbance readings for a freshly prepared 1 ppm copper solution and for delonized water. The copper extracted by the resin column could then be calculated by knowing the amount remaining in the effluent.

In preparation for analysis with the x-ray spectrometer, the molst resin samples were placed in the sample holder and put into the sample chamber below the window of the $x$-ray tube. The sample was analyzed using an $x$-ray tungsten tube with a tube potential of $50 \mathrm{kvp}$ and a tube current of $35 \mathrm{ma}$. The takeoff angle on the spectrometer was $0^{\circ}$. The goniometer was set at $45.03^{\circ}$ so that the first order $\mathrm{Cu} K$ aradiation could be detected by the proportional counter. A complete list of the settings for the x-ray spectrometer is given in Table XVI of the appendix. 
A standard sample was used to correlate $x$-ray intensity data taken at different times by calculating a relative intensity. The relative intensity is expressed by the following relationship:

$$
\text { R. I. }=\frac{I_{x-} I_{b}}{I_{s}-I_{b}}
$$

where $I_{r}, I_{s}$ and $I_{b}$ are the $x$-ray intensities of the resin, standard sample and background respectively. Background was the $x$-ray intensity from an unloaded resin. All counts were taken for one minute. 


\section{RESULTS}

The relationships between relative intensity, resin size and copper concentration are shown in Table II. The fluorescent intensity of the ion-exchange resin varied linearly with the amount of copper present. Figure 4 shows that a straight line represents the data fairly accurately. The ordinate on this graph represents a normalized intens1ty. The intensities were compared with a $50 \% \mathrm{CuCl}_{2}$ $50 \% \mathrm{KBr}$ standard sample so that the data could be both duplicated and compared or correlated with those collected on previous runs.

The effect of particle size on the fluorescent intensity for resin samples containing different amounts of copper can be seen in Figures 5 and 6 . Each graph shows similar trends of increasing intensity with decreasing particle size. The shape of these curves is similar to that predicted by Bernstein (4) for particles greater and less than infinite thickness.

The mean diameter of the particles was determined by measuring the diameter of the individual particles under a Bausch and Lomb microscope. Microscopic observation revealed that the 50-100 mesh range particles were nearly perfect spheres. The other four size resin particles 
TABLE II

EFFECT OF PARTICLE SIZE ON RELATIVE INTENSITY*

Resin (weight mean diameter in microns)

\begin{tabular}{cccccc}
\hline Cu (mg) & $\begin{array}{c}(478 \mu) \\
50-100 \\
\text { Mesh }\end{array}$ & $\begin{array}{c}(250 \mu) \\
100-200 \\
\text { Mesh }\end{array}$ & $\begin{array}{c}(112 \mu) \\
200-400 \\
\text { Mesh }\end{array}$ & $(56 \mu)$ & $(27 \mu)$ \\
\hline 10 & 0.180 & 0.181 & 0.232 & 0.243 & 0.244 \\
8 & 0.144 & 0.146 & 0.184 & 0.194 & 0.195 \\
6 & 0.108 & 0.111 & 0.139 & 0.147 & 0.148 \\
4 & 0.072 & 0.076 & 0.093 & 0.098 & 0.098 \\
2 & 0.035 & 0.040 & 0.047 & 0.049 & 0.049 \\
\hline
\end{tabular}

* Relative Intensity $=\frac{\text { Intensity-Background }}{\text { Standard-Background }}$ 


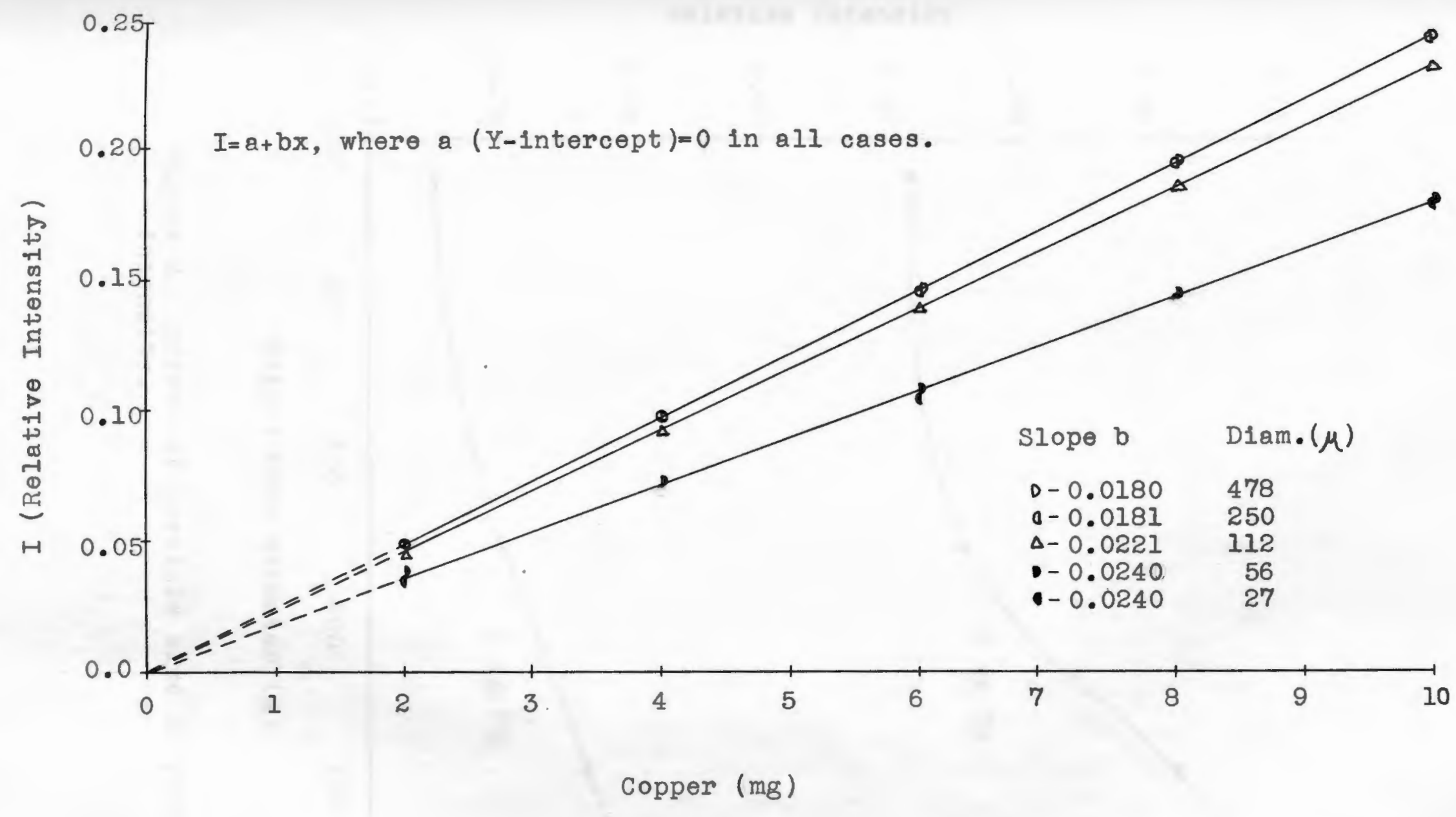

Figure 4. Influence of five resin mesh sizes and amount of $\mathrm{Cu}$ absorbed on relative $x$-ray fluorescence intensity. 


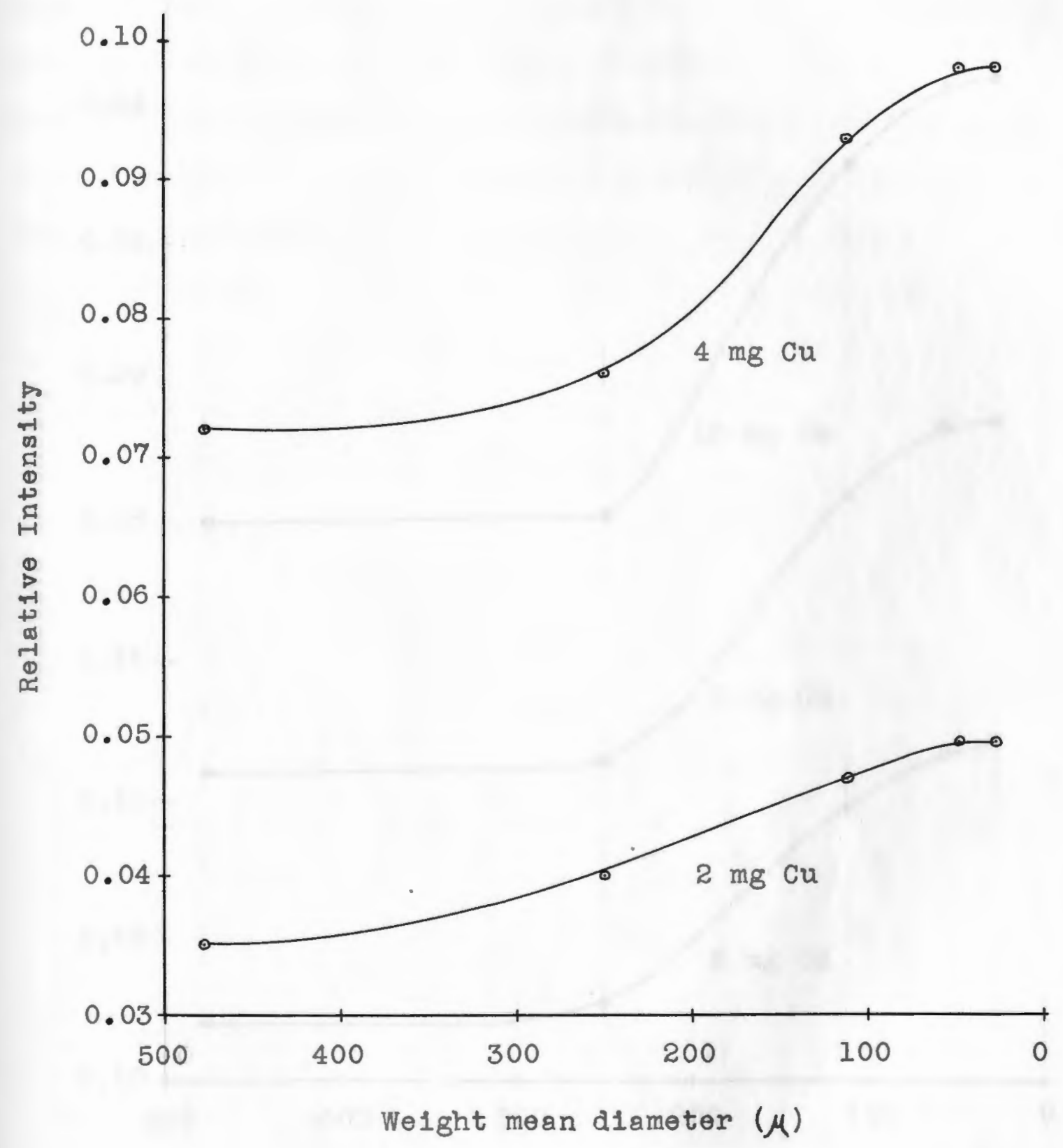

Figure 5. Effect of particle size on relative intensity. 


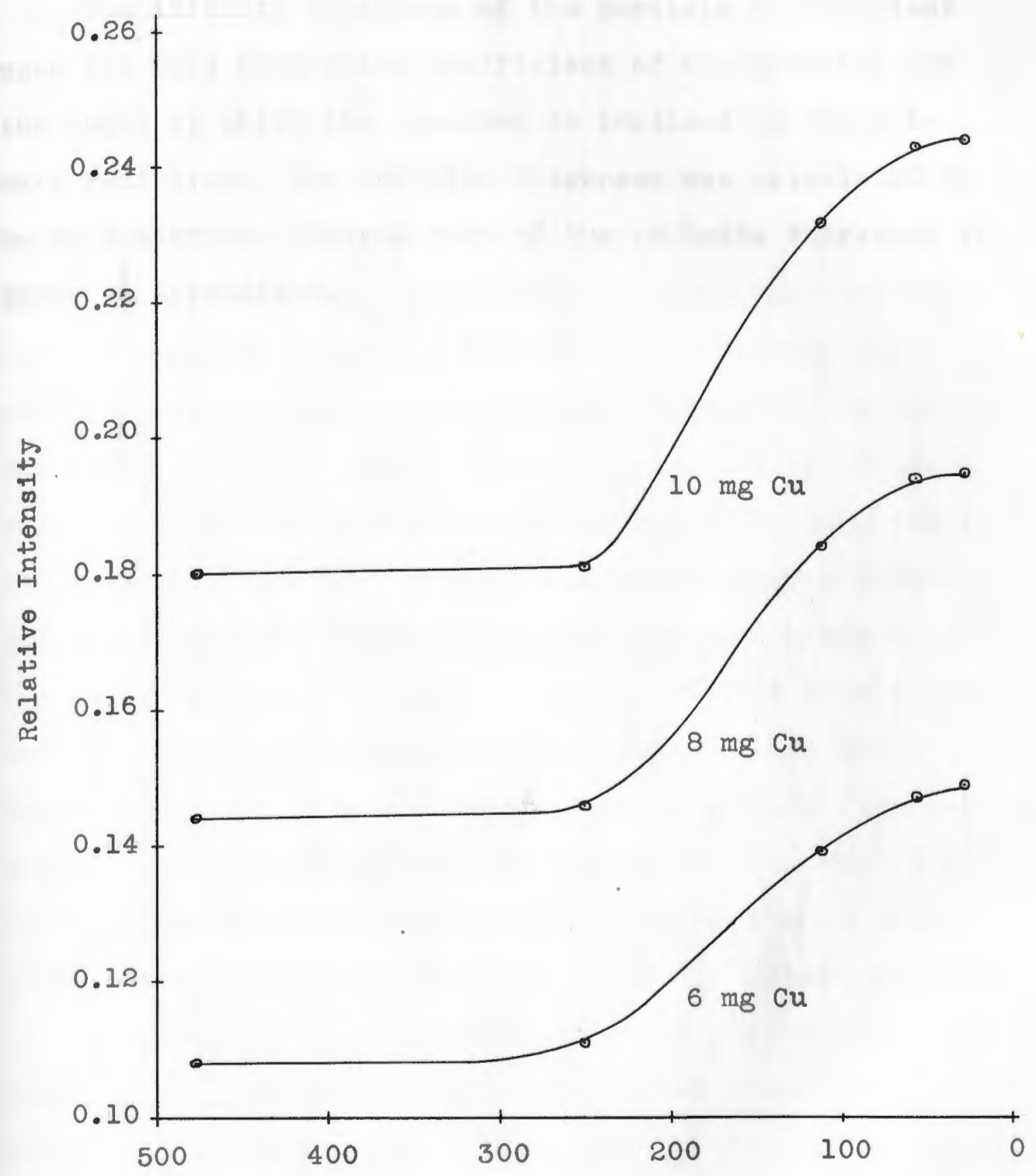

Weight mean diameter $(\mu)$

Figure 6. Effect of particle size on relative intensity. 
were spherical, although somewhat irregular.

The infinite thickness of the particle is dependent upon the mass absorption coefficient of the material and the angle at which the specimen is inclined to the primary radition. The infinite thickness was calculated to be 30.9 microns. Calculation of the infinite thickness is shown in Appendix B. 


\section{DISCUSSION}

The diameter of the columns that were first used in this investigation was $6 \mathrm{~mm}$. This size proved satisfactory for the large size resin (50-100 mesh), but the pressure drop across the resin bed for the other four sizes was too great to allow an appreciable flow rate. Reducing the amount of resin, and thereby lowering the bed helght, was limited by the size of the x-ray sample holder, since the area and depth of the resin had to be uniform for all samples. The only alternative for reducing the bed height was to use a larger diameter column. For the next three smaller resin sizes, $25 \mathrm{~mm}$ diameter columns were used. This reduced the pressure drop and increased the flow rate. A batch procedure described by Inczedy (10) was used for the smallest resin size.since the pressure drop in the column was too great to permit flow of the copper solution.

A tendency for channelling occurred with the smaller resin sizes. Channelling not only caused a less than $100 \%$ uptake of the copper, but a small part of the resin sample was also lost in the effluent. This phenomenon was easily noticed by both the excessive flow rate, and the colored path that the exchanged copper lon would leave. When channelling did occur, that particular run was discarded. 
Early in the investigation, the resin samples were dried before $x$-ray analysis so that the absorption of radiation due to the water would not be a factor. This method was abandoned when it was discovered that the loss of water created a marked change in the resin volume. This shrinkage of the particles effectively concentrated the copper which in turn caused a higher than expected fluorescent intensity.

Since the resin samples could not be analyzed in the dry state, the problem of keeping the amount of water in each sample essentially constant had to be solved. The problem was solved by keeping the resin sample in filter paper which was in contact with water. 


\section{CONCLUSIONS}

For a given resin size, the relationship between the concentration of the copper in the resin and the $x$-ray intensity was linear. This relationship agrees with Meyer's observations (11).

As the resin particle size decreased, the $x$-ray intensity emitted by the copper on the resin increased. Figures 5 and 6 show the effect of particle size on $x-r a y$ intensity. The general shape of these curves corresponds with that predicted by Bernstein (4) for a minor constituent in a powder sample (Figure 2). 


\section{BIBLIOGRAPHY}


1. American Instrument Company Roller Particle Size Analyzer Instruction Manual. A manual prepared by the American Instrument Company. Silver Spring, Maryland.

2. Bendre, S., "Determination of Trace Amounts of Tin, Uranium and Zlrconium in Water" Unpublished Master's thes1s, University of Rhode Island, KIngston, R.I., 1969 .

3. Bernstein, F., Advances in X-Ray Analys1s, Vol. 5, University of Denver, Plenum Press, New York, 1961, pp. 486-499.

4. Bernstein, F., Advances in X-Ray Analysis, Vol. 6, University of Denver, Plenum Press, New rork, 1962, pp. $436-446$.

5. Campbell, W. J., Spano, E. F. and Green, T. E., "Micro and Trace Analysis by a Combination of Ion Exchange Resin-Loaded Papers and X-Ray Spectography", Anal. Chem., 33: 787-996 (1966).

6. Cullity, B. D., Elements of X-Ray Diffraction, Addison-Wesley Publishing Co., Inc., Reading, Mass., 1967, pp. 402-422.

7. Fonda, G. R., J. Am. Chem. Soc., 55: 123, (1933).

8. Gunn, E.I., Advances in X-Ray Analysis, Vol. 4, University of Denver, Plenum Press, New York, 1960 , pp. 382-400.

9. Herdan, G., Small Particle Statistics, Elsevier Publishing Company, New York, N.Y., 1953.

10. Inczedy, J., Analyt1cal Application of Ion Exchangers, Pergammon Press, Budapest, 1966, pp. 131-156.

11. Mejer, J.W., Anal. Chem., 33: 692, (1961).

12. Ndam, S. N., "Trace Metal Analys1s Using Ion-Exchange Resin-Loaded Papers and X-Ray Fluorescence" Unpublished Master's thesis, University of Rhode Island, Kingston, R.I., 1969.

13. Perkin-Elmer Atomic Absorption Spectrophotometer Instruction Manual. A manual prepared by the Perkin-Elmer Co. Norwalk, Conn., 1962. 
14. Wheaton, R. M., and Seamster, A. H., "A Bas1c Reference on Ion Exchange", Dow Chemical Company, 1966.

15. Zeltoun, M. A., and McIlhenny, "Chemistry of Copper in Effluents from Dosalination Plants", Dow Chemical Company, 1969. 
APPENDIX A

ORIGINAL DATA 
Tables III through VII give the data obtained from the x-ray spectrometer. Background was obtalned by countIng the resin in its sodium form.

Table XVIII gives the particle distribution for the five resin sizes. Figure 7 shows the distribution on log probility paper.

The absorbance readings from the atomic absorption spectrophotometer can be found in Table XIV while Table XV gives the settings used in the aperation of the AAS. The settings used on the $x$-ray unit can be found in Table XVI. 


\section{TABLE III}

EFFECT OF CONCENTRATION ON INTENSITY

$\begin{array}{lrrr}\text { Cu (mg) } & \text { Run 1 } & \text { Run 2 } & \text { Run 3 } \\ 10 & 1401 & 1858 & 1371 \\ 8 & 1159 & 1526 & 1165 \\ 6 & 931 & 1194 & 964 \\ 4 & 697 & 887 & 752 \\ 2 & 443 & 589 & 515 \\ \text { Background } & 221 & 291 & 302 \\ \text { Standard } & 6738 & 8811 & 6377\end{array}$

Intensity values are in counts per second. Weight Mean Diameter $=478$ microns $(50-100$ mesh $)$. 


\section{TABLE IV}

EFFECT OF CONCENTRATION ON INTENSITY

$\begin{array}{lrrr}\text { Cu (mg) } & \text { Run 1 } & \text { Run 2 } & \text { Run 3 } \\ 10 & 2047 & 2029 & 1591 \\ 8 & 1730 & 1737 & 1341 \\ 6 & 1439 & 1404 & 1099 \\ 4 & 1112 & 1104 & 857 \\ 2 & 804 & 804 & 577 \\ \text { Background } & 451 & 496 & 251 \\ \text { Standard } & 9270 & 8828 & 7821\end{array}$

Intensity values are in counts per second. Weight Mean Diameter $=250$ microns $(100-200$ mesh $)$. 


\section{TABLE V}

EFFECT OF CONCENTRATION ON INTENSITY

$\begin{array}{lrrr}\text { Cu (mg) } & \text { Run 1 } & \text { Run 2 } & \text { Run 3 } \\ 10 & 2370 & 2445 & 2332 \\ 8 & 1991 & 1992 & 1979 \\ 6 & 1628 & 1617 & 1584 \\ 4 & 1240 & 1216 & 1213 \\ 2 & 852 & 832 & 836 \\ \text { Background } & 472 & 457 & 397 \\ \text { Standard } & 8726 & 8987 & 8812\end{array}$

Intensity values are in counts per second. Weight Mean Diameter $=112$ microns $(200-400 \mathrm{mesh})$. 
TABLE VI

EFFECT OF CONCENTRATION ON INTENSITY

$\begin{array}{ll}\text { Cu (mg) } & \text { Run I } \\ 10 & 2072 \\ 8 & 1723 \\ 6 & 1388 \\ 4 & 1040 \\ 2 & 691 \\ \text { Background } & 342 \\ \text { Standard } & 7461\end{array}$

Intensity values are in counts per second. Welght Mean Diameter $=56$ microns. 
TABLE VII

EFFECT OF CONCENTRATION ON INTENSITY

$\begin{array}{ll}\text { Cu (mg) } & \text { Run I } \\ 10 & 2536 \\ 6 & 1700 \\ 2 & 838 \\ \text { Background } & 411 \\ \text { Standard } & 9122\end{array}$

Intensity values are in counts per second. Welght Mean Diameter $=27$ microns. 
TABLE VIII

EFFECT OF PARTICLE SIZE ON RELATIVE INTENSITY*

Weight mean diameter

$\begin{array}{llllll}\text { Cu }(\mathrm{mg}) & (478 \mu) & (250 \mu) & (112 \mu) & (56 \mu) & (27 \mu) \\ 10 & 0.180 & 0.181 & 0.232 & 0.243 & 0.244 \\ 8 & 0.144 & 0.146 & 0.184 & 0.194 & 0.195 \\ 6 & 0.108 & 0.111 & 0.139 & 0.147 & 0.148 \\ 4 & 0.072 & 0.076 & 0.093 & 0.098 & 0.098 \\ 2 & 0.035 & 0.040 & 0.047 & 0.049 & 0.049\end{array}$

*Relative Intensity $=\frac{\text { Intensity-Background }}{\text { Standard-Background }}$ 
TABLE IX

EFFECT OF CONCENTRATION ON RELATIVE INTENSITY*

$\begin{array}{lccc}\text { Cu (mg) } & \text { Run 1 } & \text { Run 2 } & \text { Run 3 } \\ 10 & 0.181 & 0.184 & 0.176 \\ 8 & 0.144 & 0.145 & 0.142 \\ 6 & 0.109 & 0.106 & 0.109 \\ 4 & 0.073 & 0.070 & 0.074 \\ 2 & 0.034 & 0.035 & 0.035 \\ & & & \\ \begin{array}{l}\text { Background } \\ \text { (CPS) }\end{array} & 221 & 291 & 302 \\ \begin{array}{l}\text { Standard } \\ \text { (CPS) }\end{array} & 6738 & 8811 & 637 \%\end{array}$

Weight Mean Diameter $=478$ microns $(50-100$ mesh $)$.

* Relative Intensity $=\frac{\text { Intensity-Background }}{\text { Standard-Background }}$ 
TABLE $X$

EFFECT OF CONCENTRATION ON RELATIVE INTENSITY*

$\begin{array}{lccc}\text { Cu (mg) } & \text { Run 1 } & \text { Run 2 } & \text { Run 3 } \\ 10 & 0.181 & 0.184 & 0.177 \\ 8 & 0.145 & 0.149 & 0.144 \\ 6 & 0.112 & 0.109 & 0.112 \\ 4 & 0.075 & 0.073 & 0.080 \\ 2 & 0.040 & 0.037 & 0.043 \\ & & & \\ \begin{array}{l}\text { Background } \\ \text { (CPS) }\end{array} & 451 & 496 & 251 \\ \text { Standard } & 9270 & 8828 & 7821 \\ \text { (CPS) } & & & \end{array}$

Weight Mean Diameter $=250$ microns $(100-200$ mesh $)$.

*Relative Intensity $=\frac{\text { Intensity-Background }}{\text { Standard-Background }}$ 
TABLE XI

EFFECT OF CONCENTRATION ON RELATIVE INTENSITY*

$\begin{array}{llll}\text { Cu (mg) } & \text { Run 1 } & \text { Run 2 } & \text { Run 3 } \\ 10 & 0.230 & 0.233 & 0.230 \\ 8 & 0.184 & 0.180 & 0.188 \\ 6 & 0.140 & 0.136 & 0.141 \\ 4 & 0.093 & 0.089 & 0.097 \\ 2 & 0.046 & 0.044 & 0.051\end{array}$

Background (CPS)

Standard

(CPS)

472

457

$39 \%$

8726

8987

8812

Weight Mean Diameter $=112$ microns $(200-400$ mesh $)$.

*Relative Intensity $=\frac{\text { Intensity-Background }}{\text { Standard-Background }}$ 


\section{TABLE XII}

EFFECT OF CONCENTRATION ON REIATIVE INTENSITY*

$\begin{array}{ll}\text { Cu (mg) } & \text { Run I } \\ 10 & 0.243 \\ 8 & 0.194 \\ 6 & 0.147 \\ 4 & 0.098 \\ 2 & 0.049\end{array}$

Background (CPS)

342

Standard

(CPS)

7461

Weight Mean Diameter $=56$ microns.

${ }_{\text {Relative Intensity }}^{*}=\frac{\text { Intensity-Background }}{\text { Standard-Background }}$ 
TABLE XIII

EFFECT OF CONCENTRATION ON RELATIVE INTENSITY ${ }^{*}$

$\begin{array}{ll}\text { Cu (mg) } & \text { Run I } \\ 10 & 0.244 \\ 8 & 0.195 \text { (Interpolated value) } \\ 6 & 0.148 \\ 4 & 0.098 \text { (Interpolated value) } \\ 2 & 0.049\end{array}$

Background

(CPS)

Standard

(CPS)

411

9122

Weight Mean Diameter $=27$ microns.

* Relative Intensity $=\frac{\text { Intensity-Background }}{\text { Standard-Background }}$ 
TABLE XIV

ABSORBANCE READINGS

FROM THE AAS

\begin{tabular}{|c|c|c|c|c|c|}
\hline Run 1 & $478 \mu$ & $250 \mu$ & $112 \mu$ & $56 \mu$ & $27 \mu$ \\
\hline $\begin{array}{l}\text { Standard } \\
\text { Oppm }\end{array}$ & 000 & 000 & 000 & 000 & 000 \\
\hline $\begin{array}{l}\text { standard } \\
1 \mathrm{ppm}\end{array}$ & 049 & 064 & 070 & 055 & 067 \\
\hline $10 \mathrm{mg} \mathrm{Cu}$ & 000 & 073 & 000 & 000 & 006 \\
\hline $8 \mathrm{mg} \mathrm{Cu}$ & 003 & 018 & 000 & 000 & -- \\
\hline $6 \mathrm{mg} \mathrm{Cu}$ & 000 & 009 & 000 & 000 & 000 \\
\hline $4 \mathrm{mg} \mathrm{Cu}$ & 000 & 016 & 000 & 000 & -- \\
\hline $2 \mathrm{mg} \mathrm{Cu}$ & 002 & 011 & 000 & 000 & 003 \\
\hline
\end{tabular}

The absorbance readings of Runs 2 and 3 for the 478,250 , and 112 micron sizes were all 000 . 


\section{TABLE XV}

SETTINGS FOR PERKIN-ELMER SPECTROPHOTOMETER

Tank pressure setting (acetylene)............. 8 psi

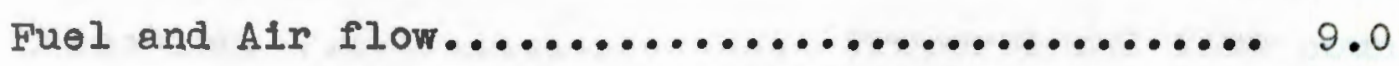

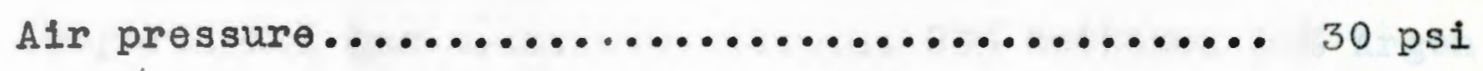

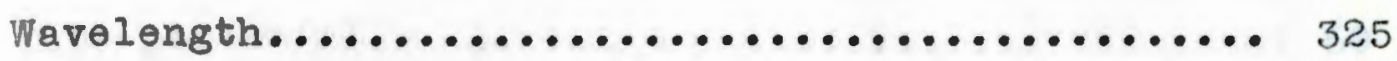

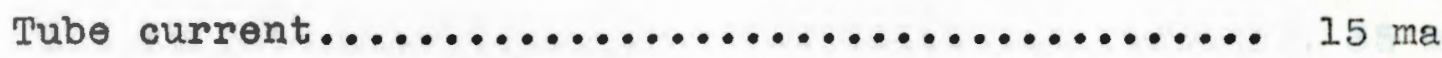
source............................... 7 Gain................................. 5

Scale............................... 2 


\section{TABLE XVI}

SETTINGS FOR G.E. XRD-S5 X-RAY DIFFRACTION UNIT

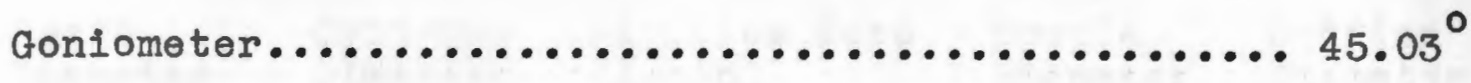
Takeoff angle............................. $0^{0}$ Detection................... Proportional flow counter Proportional gas...............90\% Methane, 10\% Argon Tube potential................................. 50 kvp

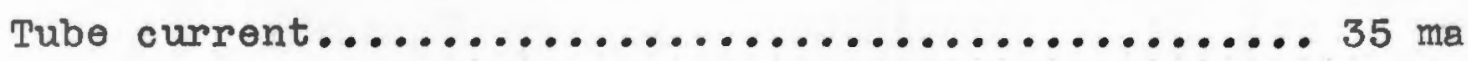
Analyzing Crystal........................ LiF 
TABLE XVII

SETTINGS FOR THE ROLLER PARTICLE SIZE ANALYZER

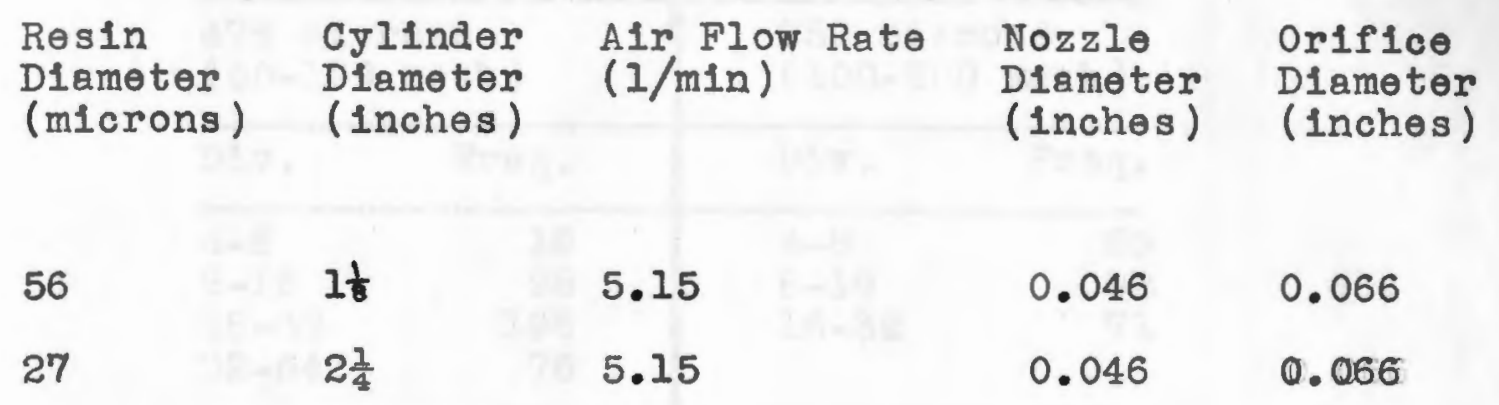


TABLE XVIII

PARTICLE SIZE DISTRIBUTION

\begin{tabular}{lr|lr}
\hline \hline \multicolumn{2}{l||}{$\begin{array}{l}\text { 478 microns } \\
(50-100 \text { mesh })\end{array}$} & \multicolumn{2}{l}{$\begin{array}{l}250 \text { microns } \\
(100-200 \text { mesh })\end{array}$} \\
\hline Div. & Freq. & Div. & Freq. \\
\hline $4-8$ & 16 & $4-8$ & 83 \\
$8-16$ & 28 & $8-16$ & 98 \\
$16-32$ & 196 & $16-32$ & 71 \\
$32-64$ & 76 & & \\
\hline $11.375 \mu / D i v$. & $11.375 \mu / D i v$. \\
\hline
\end{tabular}

\begin{tabular}{lr||lr}
\hline \multicolumn{2}{l||}{$\begin{array}{l}\text { 112 microns } \\
(200-400 \text { mesh })\end{array}$} & \multicolumn{2}{l}{57 microns } \\
\hline Div. & Freq. & D1v. & Freq. \\
\hline-4 & 239 & -4 & 120 \\
$4-8$ & 72 & $4-8$ & 135 \\
$8-16$ & 33 & $8-16$ & 91 \\
$16-32$ & 28 & & \\
\hline $5.1 \mu /$ Div. & & $5.1 \mu / D 1 v$. \\
\hline
\end{tabular}

\begin{tabular}{lr}
\hline \hline 26 microns \\
\hline Div. & Freq. \\
\hline-4 & 216 \\
$4-8$ & 60 \\
$8-16$ & 52 \\
$16-32$ & 28 \\
\hline $1.25 \mu /$ Div.
\end{tabular}




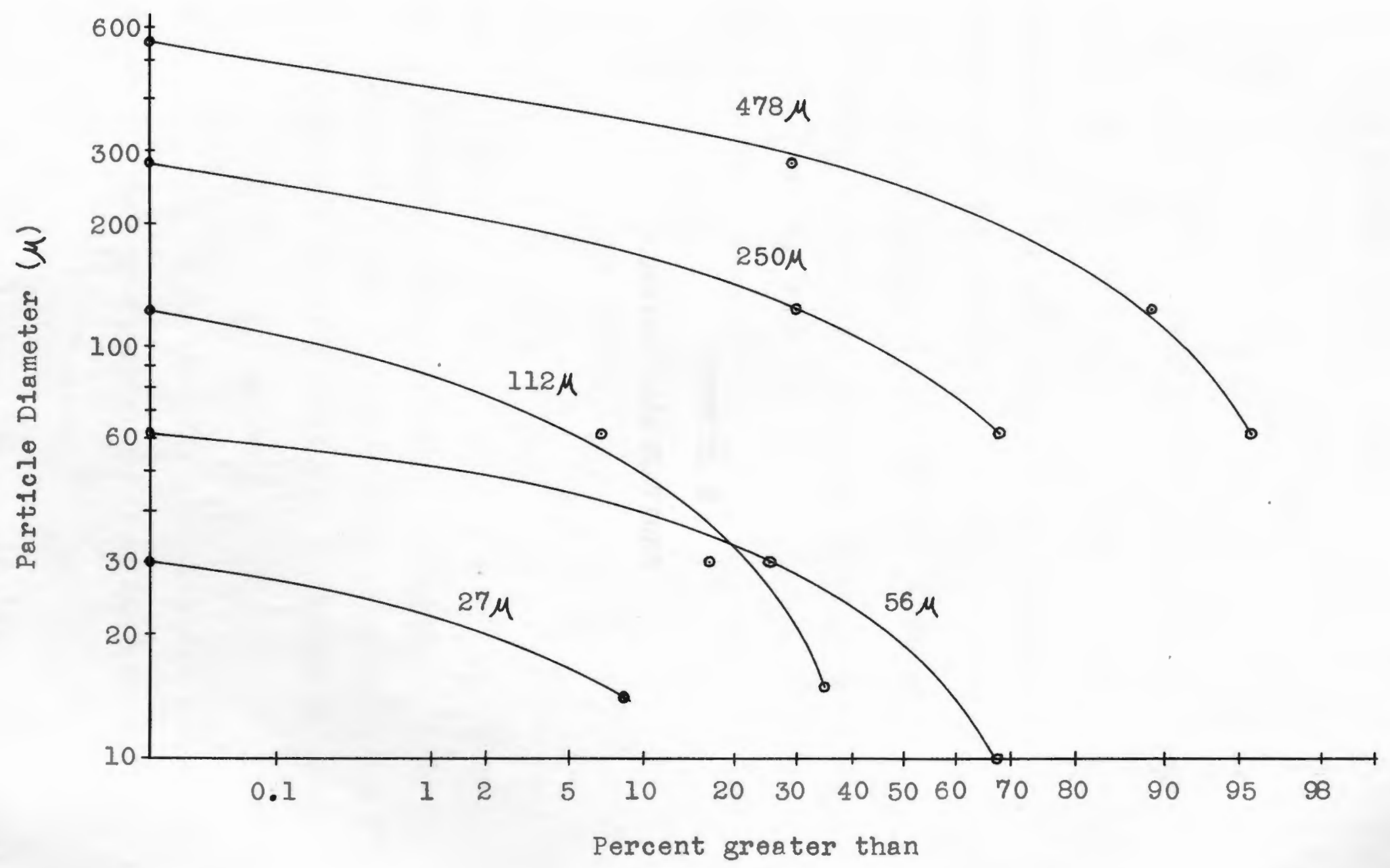

Figure 7. Distribution curves for the five resin sizes. 
APPENDIX B

SAMPLE CALCULATIONS 
1. Calculation of infinite tricrness

$$
X=\frac{\operatorname{LN}\left(\frac{1}{1-0.99}\right)}{K \mu}
$$

where $X$ is the infinite thickness, $\mu$ is the linear absorption coefficient and $k=\frac{1}{\sin \alpha}+\frac{1}{\sin \beta}=3.155$ The angles of $\alpha$ and $\beta$ are from the geoinetry of the spectrometer and are respectively $60^{\circ}$ and $30^{\circ}$.

$$
X=\frac{4.62}{1489.8}=0.00309 \mathrm{~cm}=30.9 \mu
$$

2. Calculation of $m g$ of $c u$ absorbed on the resin.

From the ALS data for the 100-200 size resin

usine the 10 ppm cu solution, the concentretion of the offluent can be calculated es follows:

$$
\text { ppm }=\frac{\text { sample reading }}{1 \text { ppm stendard reading }}=\frac{73}{64}=1.1 \mathrm{ppm}
$$

For l liter of solution this omounts to $1.1 \mathrm{mg} \mathrm{Cu}$. The anount of uptake is therefore $10 \mathrm{mg}-1.1=8.9 \mathrm{mg}$.

3. Calculation of meight mean diameter.

The weight mean diameter for the larsest fraction was calculated by evaluating the following interral:

$$
D=\frac{\int_{0}^{n} d(D w)}{\int_{0}^{n} d(w)}
$$

where $y$ is the reicht of each particle and $D$ is the dismeter. An approximation of tre integral may be given by:

$$
D=\frac{\sum D n D^{3}}{\sum n D^{3}}
$$


reicht of the particle.

Calculation of the weight mean diameter of the $50-100$ resh is as follows:

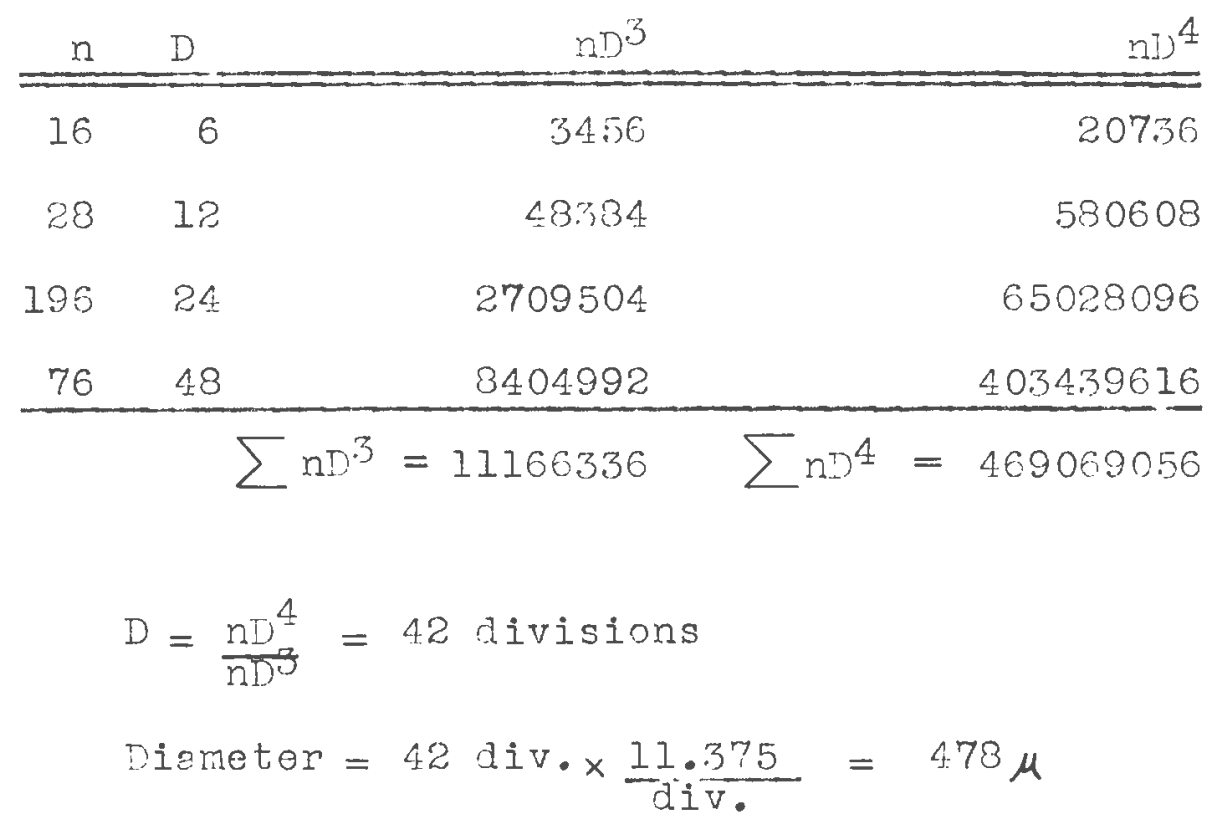

